\title{
Four Milestones in the Social and Economic Development of Czech Agriculture
}

\author{
VĚRA MAJEROVÁ* \\ Czech Agricultural University, Prague
}

\begin{abstract}
The development of agriculture in Czechoslovakia has a rich history. Some authors talk about two discontinuities (collectivisation and decollectivisation). However, in the almost hundred-year long evolution, at least four major turnarounds can be registered: the agrarian crisis at the turn of the century; the 1919 land reform; collectivisation after 1949; and transformation after 1989. The events of this century that acted as the most important impulses of social change are evidently WWI and WWII. Outside these events, the political-administrative form changed seven times during one hundred years (the Austro-Hungarian Empire to 1918, the First Republic 1918-1938, the Second Republic 1938-1939, the Protectorate Böhmen and Mähren under German occupational direction 1939-1945, the Czechoslovak Republic 19451960, the Czechoslovak Socialistic Republic 1960-1968, the Czechoslovak Federative Republic 1968-1993, the Czech Republic from 1993. In this enumeration is included the connection with Slovakia in 1918 and the separation of Slovakia on two occasions, in 1939 and 1993. Agriculture went through a rise as well as a deep fall in prestige in this history. Agricultural workers as a social group have gone through major ups and downs, and the present situation is not prosperous for them. The key problem of Czech agriculture is a parallelism of high indebtedness and a low rate of enterprise profit. The problem in rural areas is related to the high rate of unemployment and growing migration. The development of agriculture within the framework of the Common Agricultural Policy in Europe remains an open question.
\end{abstract}

Czech Sociological Review, 2000, Vol. 8 (No. 2: 157-176)

The economic importance of farming in the Czech Republic is on the decline. In spite of this, farming remains tied to the Czech countryside. It is a part of its past, present and European future. In the almost hundred-year long development of agriculture in the Czech lands and Slovakia some authors refer to two discontinuities - collectivisation and decollectivisation [Petráňová 1996: 69, Slavkovský 1995, Leščák 1995, Danglová 1995].

Reflecting deeper on farming's historical development in the Czech lands, and later in Czechoslovakia, at least four major turnarounds can be registered, which have shaped its position within the national economy, and influenced farmers' living conditions and subsequently the rural population's social structure: the agrarian crisis at the turn of the century; the 1919 land reform; collectivisation after 1949; and transformation after 1989.

The events of this century that acted as the most important impulses of social changes are evidently World War I and World War II. Outside these events, the politicaladministrative form was changed seven times over a hundred-year period: the AustroHungarian Empire to 1918, the First Republic 1918-1938, the Second Republic 19381939, the Protectorate Böhmen und Mähren under German occupational direction 19391945, the Czechoslovak Republic 1945-1960, the Czechoslovak Socialistic Republic

*) Direct of all correspondence to Věra Majerová, Česká zemědělská univerzita Praha, Kamýcká 129, 16521 Praha 6, Czech Republic, tel. +420-2-2438 2900, e-mail majerova@pef.czu.cz 
1960-1968, the Czechoslovak Federative Republic 1968-1993, and the Czech Republic from 1993. This enumeration includes the connection with Slovakia in 1918, and the separation of Slovakia both in 1939 and 1993.

\section{Historical Preface}

To understand some of the contexts of this development, we need to look into a more distant past. The rule of Empress Maria Theresa can be viewed through a nationalistic prism, as expressed by Pekař: "...she was the first to renege on the commitments whereby she had pledged to see to the independence of the Czech state, and laid the foundations for merging the Czech and Austrian lands into a single state" [Pekař 1991: 136]. The 1753 census revealed the Czech lands (with a population of 4.4 million) as making up roughly one fifth of the Austro-Hungarian monarchy's population of 21 million. The Czech lands' political importance and influence was rather marginal within the union of the Czech state, the Hungarian state and the Alpine countries.

\section{Economic and Social Reforms in Austria-Hungary}

Leaving aside the nationalist level, we can trace the economic logic along which extensive economic, educational, administrative and ecclesiastical reforms were started. The Theresian and later Josephian Cadasters gradually brought order into land ownership, primarily for tax reasons. The reform effort was also intended to stabilise rural settlement, start new villages in places of by that time extinct manors, and divide large farmsteads to increase the number of settled farming families. An important milestone was the abolition of serfdom in 1781. Historical importance can also be ascribed to the Tax and Levies Patent promulgated in 1789 which, based on the Josephian Cadasters, regulated the manors' profits and obligations to land rulers and the Church, although it was subsequently abolished in 1790 during Leopold II's rule.

The rural population was understood to be an important social group, and farming ranked among the major structural components of the national economy. The state's organised care began in those years through the setting up of farming organisations (associations in economic terms) that served for the propagation of progress in farming (by disseminating information about novel concepts, such as crop rotation, fodder and industrial crop growing and fertilisation). One of the goals pursued by farmers through association was economic defence, i.e. influence over the sale of farm produce and market protection. One of the first such associations was the 'Society for Tillage and Liberal Arts in the Czech Kingdom' (transformed into the 'Patriotic-Economic Society in the Czech Kingdom' by Joseph II's patent in 1788). Its economic and social importance is also borne out by the fact that prominent personalities from aristocratic ranks alternated at the helm of this association, for example Prokop, Count Lažanský, Josef, Count Canal, Kašpar, Count Šternberk and Prince Jan Adolf Schwarzenberg [Kubačák 1994: 144-163]. Considerable attention was devoted to agricultural education and enlightenment from the end of the 18th century, as there was no doubt that an educated farming estate was a guarantee of the monarchy's economic development.

The wars with France and Napoleon in the first half of the 19th century placed a massive economic burden on the Austro-Hungarian Empire. However, the importance of farming as a stockroom of strategic war potential (food, draught animals, fodder, and raw materials) increased. 
The revolutionary year of 1848 brought a positive change to the countryside - the abolition of manorial labour and other tributary obligations. The boom in agricultural production, related to a distinct post-war increase in the population, and therefore a sufficiently large marketplace within the Austro-Hungarian empire, further stimulated technical and technological development in agriculture. Productivity went up, and soil fertility and farming intensity increased. The market gradually became saturated and the mounting sales difficulties passed in the last quarter of the 19th century on to the second ${ }^{1}$ of the great European agrarian crises.

\section{Warnings of Agricultural Overproduction}

The agrarian crisis towards the end of the 19th century had both an economic and a social dimension. Social differentiation had already begun during the extensive changes in land and property ownership, when property was acquired by foreign aristocracy in the period following the battle of White Mountain. The legal position of the foreign aristocracy was irrefutable, and the upward mobility of the settled rural (mostly Czech) population through the social structure was relatively difficult. The countryside's economic and social difficulties were tackled in various ways and means, one of which was co-operative farming at the end of the 19th century - at first credit unions - later assuming the form of production and processing co-operatives.

The widening gap in property possessions and the deterioration of living conditions in villages at the end of the 19th century drove out a part of the poor population to seek work in both near and distant countries, including America. In contrast to the stagnation in Europe, the American countryside was experiencing a dramatic period of growth. The initially bloodstained drama of settling the American plains gradually took on the contours of a certain economic and social order. Not only the austerity and resilience of the new settler, but also the education and experience he brought with him from the former homeland played a role in this. Settlement policy employed various means, including knowledge of the then nascent rural sociology, and was directed towards a targeted construction of rural society. It was recognised that "...a farmer is not only characterised by the money-making function, whereas he is a whole complex of social functions because he is also a husband, father, neighbour, republican, the main social problem of the countryside therefore is not how to make a lot of money by plant and animal production but that a number of other issues, equally important in personal, national and human terms are at stake..." [Gillete 1928: 5]. The movement and importance of capital in American farming was at that time comparable with that of industrial capital. On the world's grain market the high quality produce of American farming, imported to Europe using relatively inexpensive ocean shipping and railway transport, started to become a factor. Soon, the European market became over-saturated, and dropping prices caused the social conditions in the Czech countryside to deteriorate even further. Small farmsteads were afflicted the hardest.

\section{The Tragedy of World War One}

Mounting social and property-related inequality marked the end of the 19th and the beginning of the 20th century. Data on property suggests that $37.6 \%$ of all soil was held by

1) The first agrarian crisis in 1818 was relatively short and was followed by a rapid growth in agricultural production. 
large-estate owners, mainly the aristocracy from the period following the battle of the White Mountain. This, however, made up a mere $0.2 \%$ of all farms. On the other hand, $68.4 \%$ of farms covered less than 2 hectares, while their owners worked a mere $5.6 \%$ of the soil [Franěk 1967]. Social inequality increasingly accentuated nationalistic undertones. Small peasants incurred debts and all too easily fell among the most impoverished strata made up of the landless and day labourers. World War One made these differences even more acute. Agriculture sent supplies to the war, but labour was scarce on small farms because village men in their active years, if they returned from the war at all, suffered from the consequences of injuries and hardship for a long time afterward. The war caused food prices to skyrocket, while profiteers of various types enjoyed fat margins from them. Malnutrition was endemic throughout the population, and poverty descended upon both the urban and the rural areas.

\section{The 1919 Land Reform}

The rather confusing process of a political coup marked the establishment of the Czechoslovak Republic on 28 October 1918. Despite this, the act itself of establishing an independent republic represented for the Czech patriotic public the ultimate in political efforts. One facet of reality was that of the hopes raised by the newly acquired national freedom, another was the threat of hunger. Ferdinand Peroutka wrote of those times: "...fear of hunger disturbed National Committee members out of complacence over the freedom acquired. They were not mistaken in seeing a danger. They feared that wildness, spawned by hunger, would spill out of houses onto the streets." [Peroutka 1933: 241].

Land reform offered a relatively logical solution to the deepening property-related inequality in the countryside, which compounded not only economic but also social and national problems. Land reform was contained in the programme pursued by both the domestic politicians and the exile government that had been preparing Czechoslovakia's establishment with the help of the Allies. The Washington Declaration stated that "large estates will be given up for the purposes of domestic colonisation". Therefore the new Czechoslovak government, in one of its first steps, passed a law on the "impoundment of large estates' (9 November 1918), intended to prevent land and property machinations before the former would be at the disposal of the State. Czech political representation was in a situation in which it had to speedily provide food and other supplies to the population, while building the system of the new republic's economic self-sufficiency.

The impoundment of estates was not easy in political or economic terms. The largest land owners were the Schwarzenbergs, the Cerníns of Chudenice, the ColoredoMansfelds, the House of Hapsburg-Lorraine, the Kinsky family of Vohnice, the Lobkovic family, and the Wallensteins etc. [Stočes 1958: 309]. A large acreage of soil was also owned by the Church, among which the Prague Archdiocese, the St. Vitus Chapter and the German monastery at Teplá were the largest owners. Economic power was logically tied to factual power. However, the extensive property rights enjoyed by foreigners elicited nation-wide indignation, and the slogan 'undo [the battle of] the White Mountain' was attractive to all the political parties [Peroutka 1933: 244].

\section{Land Reform - A Tool of Political Struggle}

Naturally, political parties differed in their views of how to effect land reform. The Agrarian Party was the strongest advocate of the reform. Thanks to its programme, which proposed the allocation of large estates into small holdings that would be made available 
to rural workers, cottiers, small farmers, rural tradesmen and the landless, the party won sizeable support among the poorer but significantly populous strata of rural people. Socialist parties pushed, in line with their ideology, for the nationalisation of large estates or their transformation into socialist co-operatives.

In mid-April 1919 the Land Appropriation Act was passed, and two months later, a law on the establishment of the National Land Office, which was put in charge of implementing the land reform. The Appropriation Act was relatively radical. The holding limits it stipulated liquidated for all practical purposes the aristocratic large estate of the type it had evolved into up to that time, with all of its economic and social pluses and minuses. Appropriation of farmland over 150 ha and any land over 250 ha was allowed. Exemptions from appropriation up to 500 ha were allowed when the aspect of 'general benefit' could be proved, while in areas where an acute shortage of soil was felt the threshold was lowered to 50 ha. Legionnaires, agricultural workers, so-called land reform victims (allowanced labourers and hands on large estates slated for parcelling) and small peasants were preferred. Large estate land was appropriated in return for handsome financial compensation, and the recipients paid in instalments for the plots they obtained in small or residual allotments.

The implementation of land reform and its results turned out to be substantially different from the original script. This reflected a number of circumstances: the radicalism of drafting the law constituted political capital which promised fast electoral gains; however, reform implementation itself was impeded by the unwillingness of those who were to be divested of huge possessions. These individuals certainly had enough economic and political tools available to hinder the reform. The power relationships and ties in the society created a dense web of barriers, against which the newly codified rights of those who hitherto had virtually no property rights could offer adequate countermoves with only great difficulty. Reform implementation dragged on until 1936, when almost one third of the appropriated land was returned to the original owners. Completion of the reform was deferred, and earmarked for after 1955.

Nevertheless, the economic and social influence of large proprietors and the foreign aristocracy was weakened considerably. The extinction of prerogatives in the emperor's court and the abolition of aristocratic titles in the country's republican organisation caused the nobility's social prestige and political influence to decline. The Catholic Church - one of the largest landowners before 1919 - retained almost all of its land, contrary to the original plans. However, its social influence also plunged.

Through strengthening small and middle farmers, the rural population's social structure changed, with acute property and social contrasts being somewhat blunted. Despite all of the above problems, land reform helped to stabilise the political and economic conditions in the First Republic; in particular, it enhanced the influence of the Agrarian Party which was the most consistent of all in reform implementation.

\section{Rising Prestige of Agricultural Specialists as a Guarantee of the Country's Stability}

Farm-produce marketing completely changed when an independent Czechoslovak republic came into being. In the first years of its existence, the new government's key task was to provide enough food to the hunger-stricken population decimated by the consequences of wartime austerity measures, shortages of food supplies which had been exported by Austria towards the end of the war, and substandard harvests from exhausted fields. Agri- 
culture was recovering slowly; for its further development investments were needed and, above all, opportunities created for farm-produce exports. However, the AustroHungarian market was lost when the republic gained independence, and it was not easy to find new outlets within accessible regions. On the other hand, the monopolistic position of Austrian-German and Hungarian capital was weakened, and Czech capital, supported by the allied countries' capital, was thus given an economic chance.

Agriculture was regarded as a very important sector of the national economy. Firsthand experience with food shortages pointed to the political and social dimension of hunger. Training specialists in agriculture, who would be able to use the country's political and relative economic independence, appeared as a priority task. The number of publications that, based on more or less extensive theoretical knowledge, treated agrarian problems was increasing. At the same time, the scientific community began to take shape, oriented towards not only the technical and technological aspects of agricultural production but also towards social issues related to the evolution of the countryside. This period also saw the development of rural and agricultural sociology, which found its domain at the Brno College of Agriculture; it was later also taught in Prague and Bratislava. Student societies, journals and movements emerged, expressing and promoting young specialists' views of life at that time, and the countryside's future. The natural radicalism of youths was fed from left-wing political directions and from the echoes of Marxism and the international workers' movement.

An important milestone was the establishment of the Czechoslovak Academy of Agriculture (28 December 1924) which immediately after its foundation initiated a number of research projects and theoretical studies focused on the economic and social problems of agriculture and the countryside. Agrarian ideology looked for and collected scientifically justifiable assumptions for argumentation in the political fight.

\section{Agrarianism - The Right and Left Wings}

Naturally, the views on the further development of agriculture and the countryside differed substantially. In the 1920s and 1930s agrarianism gradually split into two wings. The right wing was represented by Professor V. Brdlík, the left wing by E. Reich. Reich and his colleagues in the Czechoslovak Academy of Agriculture, who relied primarily on the work of the Swiss economist Laur, expounded a theory of the stability of mediumsized and small agricultural enterprises. At that time, this was quite an advanced way of thinking, which moreover matched the requirements of the 1919 land reform [Tauber 1968: 258]. Despite the onset of the Great Depression in the 1930s - which also paralysed agriculture's development and caused massive indebtedness particularly among small producers - a certain diversification of agricultural enterprises in terms of size and ownership prevented output from slumping and helped to maintain a certain level of food selfsufficiency.

In Czechoslovak agriculture, such an economic-political orientation was the consequence of developments to that time. The economic and ideological dispute over the size and character of the agricultural enterprise has in fact never been closed. The question remains as to what degree the right-wing, idealised picture of the 'Czech farmer' corresponded to historical reality; however, we cannot but see that this image was a politically pivotal ideology also for the small peasantry. In a Czechoslovak village, really large property was usually not Czech. Literary renditions of rural heroes as patriots and of wise landlords enhancing and enlarging inherited property are often marked by signs of artistic 
fiction, which helped to overcome the recurring impacts of crises and supported hope and confidence in a better future. The farmer's and the peasant's mentality was certainly individualistic, and a feature of certain reserve and familial self-sufficiency can still be observed in the village today. However, along with this individualistic approach, the principle of the self-help co-operative began to evolve and was particularly strong in this country. Co-operatives provided that dose of economic and social co-operation which was absolutely essential for small producers to survive, while being a useful complement to the existing institutional structure for larger agricultural enterprises.

\section{Beginnings of Czechoslovak Co-operatives}

The roots of the co-operative movement date back to the $1890 \mathrm{~s}$. The intensification of agricultural production, which began in the mid-18th century, contributed to the significant development of the countryside. Crop rotation replaced fallow land, economical sowing in rows replaced broadcast sowing, and inorganic fertilisers started to be used in addition to organic manure. The introduction of new crops, mainly sugar beet, fodder crops, and fodder root-crops, broadened the feedstock base and improved the productivity of animal production. Cattle and pig head counts went up. The improved health of farm animals was reflected in the higher average weight and yield of animals. Ever more frequently, menial work was being replaced by agricultural machines. Large farmsteads flourished, and agricultural production generated good profits for their owners. Czech agrarian capital began to centralise and emancipate itself at the turn of the century. The Agrarian Party was founded in 1899 and became, particularly after Czechoslovakia was established, the most influential Czech power.

Small farms barely survived and tried to avoid debt. Their productivity was incomparably lower. Their market staples included sheepswool and grains. Storage facilities were limited, and grains were therefore often sold immediately after harvest rather than before sowing when their price peaked. When the local market was saturated, farmproduce sales depended mainly on middlemen, who pushed purchase prices down to a minimum. The agrarian crisis thus eradicated small farms one by one.

The above economic difficulties prompted the peasantry to set up various self-help societies. Raising loans was very difficult for the less affluent strata of farmers. Cooperative credit unions therefore met with a strong response in rural areas and expanded rapidly. They were initially set up on the Raiffeisen system, but soon the Czech name Kampelicka took root, after the first Czech promoter of civic self-help, Dr. Cyril Kampelík. In the 1890s, there were several dozen such Kampeličkas, several thousand at the turn of the century, and almost 4,500 in 1933. In addition to Kampeličkas (unlimited liability co-operatives), limited liability co-operatives (trustee savings banks) started emerging.

The co-operative sector reached a period of great boom within a short time. Other types of co-operatives emerged: marketing co-operatives (which facilitated the sale of farm produce and the purchase of industrial goods for farmers); warehousing cooperatives; production and processing co-operatives (e.g. dairies, distillers, starch makers, linen and flax breaking shops, flour mills, bakeries, engineering, power generation), pastoral and fisheries co-operatives etc.

The co-operative idea attracted almost all of the rural social strata. For small peasants, raising a loan was the greatest problem. Kampelickas were the most accessible type 
of self-help, non-profit co-operatives for them because they addressed fundraising difficulties, required lower membership shares, and each member had only one ballot in voting at general meetings. Besides accepting deposits and providing loans, Kampeličkas also facilitated the conversion of mortgage debts, joint procurement, and the marketing of members' products. Profit co-operatives (production, processing etc.) were mainly set up by medium and large farmers, and the state also was in favour of them. These cooperatives required high membership shares and extensive obligations, for their main purpose was to collect sufficient capital for investments. Decision making at general meetings was very often related to the member's equity stake. The variability of cooperatives made it possible to draw on the most suitable sources of raw materials and adjust co-operatives' operations to the conditions prevailing in each particular part of Czechoslovakia.

\section{Agriculture is a Strategic Sector in Wartime}

The German occupational forces focused on maintaining the productivity of Czechoslovak agriculture. Credit unions and production and consumption co-operatives represented concentrated capital, while offering a clear and functional system of farm-produce production and distribution. Through a relatively simple reorganisation (abolishing general meetings, implanting their own trustees and commissioners into all key positions in cooperatives and their associations) the Germans won control and insight. Food and raw materials were redistributed (mostly to Germany), and the financial centres of cooperatives were linked directly to the Reichsbank. Agriculture supplied the army and the civilian population, and it would not have been effective to destroy this background. Development in torn-away border areas took a different course than in the occupied inland, but overall Czechoslovak agriculture was not damaged by World War II in any significant way.

The moral damage was much greater: the collaboration of many large landowners and businessmen with the Germans; the discrediting of the Agrarian Party; and, above all, flagrant usury and profiteering - a phenomenon associated with every period of material want and social instability. People associated the long-awaited end of the war with hopes for a return to pre-war values, including the recovery of the co-operatives' democratic principles [Špirk 1959: 5-15].

\section{Post-War Agriculture}

War-inflicted damage was gradually removed in the first months after the war. The consequences of bombing were remedied in the large cities and industrial areas, production was resumed, neighbours and relatives were reunited, and families sought for their missing members. Prisoners returned home from concentration and forced labour camps, and soldiers came back from their foreign resistance units. The post-war formation of Czechoslovak political and power structures was distinctly marked by agreements signed between the superpowers before the end of the war. Czechoslovakia fell within the Soviet Union's sphere of control, with all the consequences that were to stem from this soon after.

Although the manner and results of international political talks at the last stage of the war did signal the direction in which the country's future development would be headed, not even the heaviest sceptics could fathom its future reaches. Only those who had come into personal contact with this ideology in the Soviet Union knew what com- 
munism, or its ideological precursor, socialism, actually meant. Their fates varied, but they were almost always dramatic and tragic. Some intellectuals of the First Republic identified with the notions of 'the people's government' and accepted and defended them quite, uncritically. It is difficult to identify today the role played in these attitudes by naivete, political blindness, fear, speculation or genuine enthusiasm and belief. Some individuals made attempts, usually unsuccessful, at critical reviews. However, in the pre-war climate of the acute threat of German fascism, they were neither listened to nor supported, because a pessimistic statement that deadly danger was imminent from both west and east sounded so hopeless that even rationally thinking people refused, perhaps due to their self-preservation instinct, to take notice of it.

The Communist Party of Czechoslovakia took over political initiative, including the formulation of the objectives of agricultural policy. The promise of soil and confiscated-property allocation met with a favourable response on the part of other political parties - Social Democrats, the People's Party and the National Socialists. Reservations were not even raised by the rationally thinking agrarian experts of the 1930s, or the London exile of 1940-1945.

The Košice Governmental Policy Statement did include formulations that - with the passage of time and with knowledge of the subsequent developments in retrospect might have rung a warning sound. ${ }^{2}$ However, they were justifiable in a way at that time: a certain radicalism was perceived as a legitimate effort to make right the wrongs of war, and matched the thinking of the peasantry's middle and lower strata with their experience of the 1930s agrarian crisis and the occupation regime. For the time being, collectivisation did not appear on the agenda declared in the Party's agricultural policy.

\section{The German Expulsion Trauma. Newcomers Settling in Border Zones}

It is to be agreed that the expulsion of almost 3 million Germans from Czech border zones is one of those political decisions that are reflected in the entire lives of the actors and their descendants. Assessment is up to historians and political scientists; mutual making-up for the wrongs is up to political representatives, civic groups and other institutions.

\footnotetext{
2) "Responding to the calls of Czech and Slovak peasants and the landless for a consistent implementation of a new land reform, and motivated by efforts to, first of all, tear Czech and Slovak land once and for all from the hands of foreign German-Hungarian aristocracy, as well as from the hands of the traitors of the nation, and place it in the hands of the Czech and Slovak peasantry and the landless, (...) the National Land Fund shall be established. The National Land Fund will include all land, buildings, livestock and dead stock if these have been owned by: German and Hungarian aristocrats and large estate owners, irrespective of citizenship; German and Hungarian citizens of Czechoslovakia who actively helped to break up and occupy Czechoslovakia, who betrayed the nation and actively supported German and Hungarian occupants; shareholding and other companies that were managed by persons as above categorised. The above land fund and the property connected therewith shall be confiscated without compensation. The relevant national committees assisted by peasantry commissions shall carry out the confiscation and temporary management of the confiscated property pending the implementation of the land reform. Farmland found at the disposal of the National Land Fund shall be allocated in Czech lands to Czech cottiers, and in Slovakia to Slovak and Ukrainian cottiers, small and medium-sized peasants as also to agricultural workers, with preference to be given to those who have merit for the national liberation struggle..." [Košický... 1945].
} 
In this text, this event is included as a mere statement of a historical fact that changed the character of large rural parts of the Czechoslovak republic.

From the purely economic point of view, the expulsion of the Germans, and the confiscation of their land and real and personal property caused a distinct change in the national cadaster of farmland. This land and property could then be allocated to applicants. However, this act was an extremely unfortunate one from a moral point of view. Although history gives evidence of the defeated being treated by the victors in this way, it in no case justifies such solutions. From the social perspective, a period of dramatic vertical and horizontal movements in the rural population's social structure, and of changes in the population's ethnic pattern, was opened up.

The newcomers included Czech and Slovak citizens and repatriates from other countries (Rumania, Bulgaria, Volhynia in Russia. etc.). Settling in the border zone meant a considerable, socially upward step for many of them. Maximum land allocation was 13 ha, which could suffice for an average family's living. Interest in land and confiscated property was substantial. The Ministry of Agriculture made use of this situation to strengthen the Communist Party's position, and rushed to issue ownership deeds for the allocated soil. In this way, the communists wanted to gain as much influence in the countryside as possible - influence they would be able to capitalise on in elections.

This massive social mobility was wrought with negatives. Besides honest and genuinely needy people, easy property acquisitions attracted many adventurers who had no intention to toil the acquired soil or to appreciate property - their aim was to make as much money as possible as quickly as possible, and then to vanish. Border areas were being settled and devastated at the same time, and people's fates mixed and intertwined. Primarily agricultural workers and small peasants benefited from farmland confiscation between 1945 and 1948. The social groups of the most impoverished agricultural workers of the pre-war countryside - the farm hands and servants, the landless, the allowanced labourers - virtually disappeared. The group of middle peasants was reinforced and became the strongest economic and social group in the Czechoslovak countryside. However, their satisfaction was not to last long, and rural life was to be switched over onto a different course.

\section{Nationalisation in 1948}

Very soon after the war, in early 1946, the communists laid down at their 8th Congress a guideline concerning the co-operative sector in general, and co-operative farming in particular. $^{3}$ The communists pushed for the co-operative sector's unification as early as before the war without success. They succeeded in July 1945 when the Central Council of Co-operatives was established as an umbrella organisation controlling nine separate cooperative unions. ${ }^{4}$

\footnotetext{
3) The key policy of co-operative farming was formulated as follows: "To provide for effective support to co-operative farming and its full democratisation and simplification so that co-operative farming can become an effective tool in the restructuring of the entire distribution system, as well as for production cost cutting in agriculture." [Protokol...: 145].

4) Association of Co-operatives for the Elevation of Agricultural Production; Association of Warehousing and Related Agricultural Co-operatives; Association of Agricultural Engineering Co-operatives; Association of Co-operative Credit Unions; Association of Production and Labour 166
} 
The party's agricultural policy was launched by extensive purges, particularly at the managerial level. Most directors and senior executives of the Union of Agricultural Co-operatives and of the co-operatives' federations were dismissed, and replacements in middle-level executive positions were initiated.

The country's Constitution of 9 May 1948 declared the democratisation of cooperatives. However, democratisation was meant in the communist interpretation of this word. ${ }^{5}$ The Constitution explicitly prohibited money-making activities in the capitalist way, while failing to specify the sources of general welfare. Unification of the cooperative sector (workers', artisans', trade and farming co-operatives) was effected through a law on the Central Council of Co-operatives passed in July 1948. In December that same year, the operations of all the previously existing co-operative marketing institutions (particularly Kooperativa, Moragra, Zemka, Perut' and other marketing societies) were terminated; the entire purchase of farm produce and its processing were subjected to monopoly. Co-operative credit unions were made directly connected to the State Bank of Czechoslovakia, and became part of the state's financial sector. The existence of self-help co-operatives thus lost both raison d'être and room for operations.

After February 1948, the gradual nationalisation of industry, the financial sector, and foreign and domestic wholesale trade continued. Part of the transport system was also nationalised. Still, private small-scale production, larger farmsteads in the village, and some private factories and trades in the city continued to hold out.

\section{Collectivisation: Purpose and Punishment}

It was obvious that the village would not be spared the changes brought about by the communist regime for too long. However, it was not so easy to appropriate and nationalise farmsteads in the village. The post-war land allocations did meet the need of a considerable number of small peasants, but tens of thousands of hectares remained uncultivated and unsettled in border areas. Alongside the inflow of people into the village, an outflow of village people into towns also continued, and agriculture began to feel a shortage of skilled labour. It was untenable at that time in both political and economic terms to launch collectivisation because eradicating large and well-performing farming units would undermine supplies to the population.

The approach of stepped-up pressure was taken, mainly through increasing the obligatory deliveries, taxes, price disadvantages etc., to an extent that would become unbearable for the farmers and that would force them into a different solution - joint farming. The possibility of harsh penalties became a programme, and the state's highest representatives made no secret of that. ${ }^{6}$ In February 1949, the National Assembly passed

Co-operatives; Association of Small Trades Co-operatives; Association of Housing Co-operatives; Association of Community and Cultural Houses.

5) Co-operatives are defined as "... an association of the working people for joint activities, the purpose of which is to improve the standard of living of the members and other working people, but not to achieve the greatest profits possible from the capital invested. The state supports the people's co-operative sector in the interest of the development of the national economy and general welfare." [Ústava... 1948].

6) "We must push hard for the meeting of all state and public obligations on the part of the residuals of the capitalist strata in the city and the countryside, and in case of any anti-state and unlawful 
Act No. 69 on Standard Agricultural Co-operatives, whereby all the co-operatives hitherto existing in a village were amalgamated or transformed into a single co-operative, while the formation of additional Standard Agricultural Co-operatives (SAC) was launched. These newly formed SACs did not operate according to the pre-war principles of co-operative farming; instead the 'Standard Statutes' of 1949 were imposed on them. The Standard Statutes had been approved by the Ministry of Agriculture and regulated in detail the terms of reference of co-operatives' bodies and the way of their management.

Thereafter, an intensive campaign was launched which emphasised the advantages of joint soil-working and concentrated animal production. In parallel with the first wave of collectivisation the project of exporting the class struggle to the countryside was continued. Owners of more than 20 ha, and later 15 ha, were labelled as the 'village rich men'. Experts were instructed to find "other criteria to define capitalist elements in the countryside than soil acreage" [Kaplan 1993: 224-225]. The principal tools deployed in the rural class differentiation policy included class-based scheduling of produce supplies and purchase; the forced sale of machines; a ban on employing labour; forced threshing and sale of grains; forced leasehold; forced land swaps; the seizure of textile and footwear rationing vouchers; a ban on killing one's own hog for one's own needs; and other restrictions. The economic and social pressure exerted on peasants mounted, inspired by the brutality of the Soviet model of collectivisation.

The rural élite of able and industrious agricultural workers was systematically liquidated in economic and social terms; at the same time, the process of devastating the cultural and social heritage of village co-operation continued. Mass-scale unlawful actions and court trials, plus existential and legal uncertainty hit agricultural workers on the most sensitive point - the peasant was deprived of the ability to make decisions about his own land, which was taken from or allocated to him, he was not allowed to buy machinery or make decisions about his products. Civil freedoms were lost, officials were not elected but appointed, and all organisations that defended farmers' interests ceased to exist. Communist functionaries and the Ministry of Agriculture - the principal promoters of collectivisation [Kaplan 1993: 228-231] - proclaimed themselves to be representatives of peasant interests.

Not only the owners themselves but also their families were hurt. The children of the afflicted peasants, and also of tradesmen and other enemies of the state, were denied access to education. They were often forced to remain in agriculture as menial workers, and were not allowed to look for any other job in the city or try to acquire other qualifications. Never before and never again were agricultural workers exposed to such strong pressure and degradation.

\section{Loss of Prestige}

In the 1950s, disillusion flooded the countryside, hand in hand with fear and uncertainty. Forcibly established SACs failed to report good results for a long time. A number of SACs were wound up due to bad management, and their land and property were taken over by state farms. The co-operative peasant's standard of living was very low. Remuneration based on the 'labour unit' did not reach the average of fixed remuneration at state farms and other state-owned companies, and so the croft, although always labelled

activities of such elements, even for the imposition of property-related penalties." [Klement... 1949: 287]. 
as a 'private-capitalist anachronism', was preserved in the village to compensate for the low income and to provide food to village households.

The consequences of collectivisation as a violent intervention in human fate and the country's economic mechanism remained manifest for a long time. The agricultural profession's social prestige dropped to a historical low. After a period of a ban on education for children of kulaks and other class enemies, the conditions relaxed somewhat at the end of the 1950s in that they were permitted agricultural education; however, for some of them, the ban on any other type of education remained. Studying agricultural sciences thus represented punishment for the parents' alleged guilt. Paradoxically, however, a college degree in agriculture was grounded on a good standard in this country, and many émigrés after 1968 applied it successfully outside Czechoslovakia. Nevertheless, the loss of free choice, whether of education or vocation, heavily deformed the relationship of agricultural workers to other social groups, and that of the majority population to them.

SACs slowly consolidated at the end of the 1950s and in the 1960s, and underwent four stages of unification. ${ }^{7}$ In the early $1960 \mathrm{~s}$, a transition to fixed financial remuneration was prepared (to replace remuneration based on labour units), conditions of social consumption gradually levelled, and the principles of corporate consumption were adjusted. By this time, the first generation of violently collectivised farmers was being substituted by a second generation, less burdened by painful memories and injustices. Individuals who did not succumb to the pressure of collectivisation and worked their holdings independently (only a very small percentage of the total number of workers in agriculture) served as living examples of the way resistance to the state's power wound up; they more or less vegetated, and their children usually did not follow suit.

The social dimension of collectivisation in agriculture consisted in a violent breakdown of the until then existing social structure, and through various limitations erected railings within which a different social structure would form, adjusted to the needs of carrying out the idea of socialist large-production farming. As time went by, the differences originally spawned by ownership gradually blended. The generational rollover of agricultural workers caused the existence of private land and production means ownership to be almost forgotten. Such an existence had no practical meaning, and did not fit into the value system of the socialist way of work and life [Majerová 1997: 111].

The short episode of the 1968 Prague Spring did not influence the Czechoslovak village too much. Although efforts appeared to create alternative types of economic entities, as well as attempts at returning to private farming, the period of relaxation was too short for any marked changes to occur. Besides, political turmoil was taking place in the cities; the countryside watched it at a distance, with moderate interest and mistrust. The subsequent invasion by Warsaw Pact troops hit the cities dramatically, while the villages only registered massive military movements and listened to the fire in the distance.

7) Co-operatives of the first type did not differ too much from other, for example engineering or warehousing, co-operatives. All private property remained preserved, but some operations in plant production were carried out jointly, such as sowing and harvesting. Co-operatives of the second type operated joint plant production on fused plots while animal production remained private. Cooperatives of the third and fourth type already had joint plant and animal production, and differed only in the size of private property (croft) which had been left to members for their own needs. 


\section{Normalisation in the Countryside}

The Soviet occupation and the subsequent 'normalisation' of economic, political and social life were something of a shock at first. Another strong wave of defections swept away prominent personalities from all areas of economic, political and social life. The countryside was, however, less primarily afflicted than urban communities, as there were no centres of intellectual resistance there that had to be broken.

In respect to further development, an important aspect was that of the massive subsidies to agriculture and the structural changes in the early 1970 s, oriented towards enlarging the original agricultural enterprises, co-operatives and state farms. ${ }^{8}$ There were multiple reasons for enlarging agricultural enterprises. In addition to confirming the embarking on the road of socialist large-scale production agriculture and precluding any alternative types of farming entities, extensive replacements took place in the controlling apparatus of agriculture, in line with the course taken towards filling most positions by nomenclature Party members. Mergers and amalgamations constituted strong interference in the social structure of agricultural workers because their position changed in larger terms.

This period, generally considered in our society as the one with the lowest degree of freedom, probably did not imply such a meaning for the rural population, or at least not so strongly. The dissent movement's influence was not felt in any marked way in the village, and if so, then usually in relation to urban communities. The transparency of social ties and social control precluded any other manner of social behaviour and conduct than the ones that were connected with meeting work and family related responsibilities. Most leisure time was devoted to home improvement and household upgrading, and care for gardens and private plots. On the other hand, the urban population began to gradually discover the charm of spending their leisure time in nature, working on their own little house or cottage. That period saw a surge of interest in weekend 'cottaging' (a terminological coinage to express what has become a deep-rooted, virtually second life). Its significance obviously did not rest, in the mere possibility of owning private property, but lay also in the opportunity of having one's own world in which one's own life could be lived, frequently with an emotional undertone of a return to the familial roots of rural ancestors.

It is to be noted for the sake of impartiality that amalgamated undertakings posted good economic results for a certain period of time. In fact, a similar trend of the concentration of and specialisation in agricultural production was then underway in advanced capitalist countries, only the ways and means of fusing agricultural units to form large farms differed - they were based on free competition in free-market economies. The capitalist state stepped into this process as a regulator in cases when social impacts on small farmers were too drastic, mainly by supporting their retraining for other professions in areas where they could not survive economically as small agricultural producers. How-

8) At the beginning of collectivisation in 1950, an average SAC had 359 ha of farmland and still in 1960 , by when average acreage had increased to 420 ha of farmland, an average SAC equalled in size one community's area (there were 10,816 SACs for 19,343 settlements in Czechoslovakia). Before 1970, amalgamations went on relatively slowly (farmland area averaged at 625 ha per $\mathrm{SAC}$ ). The figures are 1,325 ha in 1975; 2,476 ha in 1980; and 2,507 ha in 1982 remaining so until 1990 (2,504 ha). 
ever, Czechoslovakia's socialist, mass-producing agriculture passed its zenith in the second half of the 1980s, at which time its economic decline began, accompanied by the disintegration of the state's political power.

\section{Transformation of Agriculture}

The end of the 1980s was marked by the Party's and the Czechoslovak government's tenacious efforts to preserve the status quo. The unwillingness to adopt an economic or social reform was understandable, for even slight changes would pose a threat to most of the power positions based on the Party's leading role. New fashionable buzzwords started appearing in agricultural planning: 'effective intensification', 'development of motivation', 'incentive', 'optimum use of human potential', 'looking for reserves', 'activation of the human factor'. The process of controlling large agricultural enterprises, with limited possibilities for change and independent decision making, was bound to be marked by degeneration. Remuneration was heavily levelled out; on-job promotion depended on neither objective factors nor subjective qualities, but on the Party bodies' decisions. Opportunities for increasing the standard of living were restricted if connected with a spirit of enterprise or private initiative. On the other hand, low quality or incomplete work was tolerated and silently overlooked, and theft was penalised relatively moderately. The most serious defect that for almost forty years arrested the natural evolution of corporate structures was a personnel policy based on classifying people into nomenclature ranks. This situation was no longer satisfactory even for those who had originally profited from it because an economic downfall started assuming all too clear contours.

\section{Renewal of Private Farming}

The political, economic and social changes after 1989 were anticipated with hope in the rural areas. However, nobody knew clearly what they would imply. Attitudes to property restitution and privatisation were very positive in general, but considerable reserve persisted in specific cases. A media campaign in early 1990 for the recovery of private farming missed the mark completely, because its vagueness, and the ideologically fuzzy term 'Czech farmer', did not find a response in the countryside. Nobody was able to explain exactly what traditions skilled secondary and college educated people, with experience in modern agricultural production, should return to. Quite the contrary - these people knew how to orient themselves in the maze of legislation and regulations, they were capable of sober economic thinking, and if they mustered up courage for private farming, then it was based on the concept of an intensive agricultural undertaking equipped with up-to-date technology and leased land. In contrast to them, a stratum of private peasants emerged, working small, up to 1 ha holdings, with a low level of mechanisation and a purely extensive character of farming lacking any market aspect. The village society started differentiating.

\section{First Steps of Transformation}

The first half of 1990 was marked by symptoms of a preparatory period. The economic reform scenario, prepared by the Czechoslovak government and approved by the Federal Assembly, was published in September; it did contain parts of a social reform script, but devoted only marginal attention to the agri-food complex and its labour resources. Undertakings (agricultural co-operatives and state farms) therefore continued their operations in the original extent, structure and orientation, but started preparations for systematic 
changes. These preparations were of an official (drafting the procedures for disintegrating enterprises into smaller units; collecting and preparing documentation and accounting statements for privatisation; settling restitution claims, etc.) as well as unofficial (drafting legal and economic documents for transactions involving transfers of state-owned and cooperative property into private hands) nature. The absence of laws protecting the legality and transparency of the privatisation process, inefficient overseeing, networking, welloiled organisation and the unscrupulousness of the former power wielders, all made it possible to permit steps which helped such individuals to enrich themselves while depriving the country's economy overall [Majerová 1997: 126].

People with low qualifications experienced the greatest disappointment. They were compelled, some of them for the first time in their lives, to make decisions on their professional and personal future. If they intended to stay in the same enterprise, they had to reckon with transformation consequences, i.e. much greater requirements on employees, less certainty about keeping the job, and sometimes lower wages. If they intended to start their own business they would have to assume responsibilities related not only to changing their job but also their lifestyle. If they decided for private business or private farming during the transformation period, when legislation and virtually all external relationships were undergoing change, they faced a difficult task.

\section{Status of the Rural Society}

Agricultural workers did not nurture too many illusions about the destiny of their enterprises, but at the same time could not rid themselves of the notion that it would be desirable to preserve most of the social certainties and advantages awarded to them so far (onthe-job catering, contributions to children's and adult recreation, certain advantages for retirees, social assistance, contributions to kindergarten operation, stabilisation and recruitment benefits, contributions to workers' training etc.). The transformation reality was, alas, different.

Agricultural enterprises and state farms were turning into different types of legal entities or businesses run by individuals - private farmers, trading companies, cooperatives, state-owned companies and other legal forms. As a result of property transformations, the agricultural active-age population had by 1995 differentiated into four major social groups:

1. Owners of interests in trading companies;

2. Owners of interests in co-operatives;

3. Owners and tenants of agricultural land and property;

4. Employees of companies, run by both legal entities and individuals [Report... 1996: 15].

Transformed undertakings started improving productivity and reducing work force numbers. The first waves of reductions included people of retirement age and problematic workers with low work moral. At the same time, those who could easily find a better placement elsewhere - artisans, construction crew workers, drivers, repairmen, able office workers, and middle and upper management people - left voluntarily. Subsequently, dismissals were compelled by the company's economic standing, and jobs were lost by those who really wanted them but failed to meet qualification or other requirements (for example mothers of young children, senior citizens, handicapped and less adaptable per- 
sons). The threat of unemployment in agrarian areas turned into reality, and the rate of unemployment of agricultural workers, or rural people earlier tied to work linked to agriculture, started markedly exceeding the national average.

Changes in social status and extensive vertical and horizontal social mobility have distinctly influenced the countryside. Since the properties returned in the restitution process were usually not too large (middle and lower peasantry was the single strongest group in the pre-war Czechoslovak countryside in terms of numbers), the number of outright rich people has not in fact increased in villages. Claimants often received their land and property back in a state that did not make it easily saleable, and considerable investments were needed to start intensive production. If after all they made investments, they incurred debt and used the revenues to cover loans.

Just as prior to 1989, employees who had stayed in transformed undertakings now devote a considerable proportion of their leisure time to working their personal plots, which, given inflationary food prices, have resumed their basic importance as a source of cheap and quality food. However, marketed products yielded by personal plots rarely help to increase the family's standard of living in any discernible way.

Those who had lost their farming jobs found themselves in an unenviable situation. More or less successful job hunting in the same or similar profession, switching professions, retraining, resignation of a skilled job, commuting or moving house could be considered. But ties to the family's house and personal plot, growing transport service prices, and obligations to other family members (mainly women), all meant that the above alternatives offered more minuses than pluses. A hard differentiation of social groups has come into being, and horizontal as well as vertical mobility have accelerated. The most endangered groups of the rural population are: private farmers with the main income from agriculture managing on a small acreage of land (to $10 \mathrm{ha}$ ), seasonal labourers (seasonally unemployed), women (poorly qualified, about 50 years, mothers of small children, lonely women), long-time unemployed agricultural workers with low qualifications, family members (without qualifications) employed in private farms, disabled persons.

\section{Present Situation}

The key problem of Czech agriculture is the parallel of high indebtedness and a low rate of enterprise profit. The indebtedness of agricultural enterprises is permanently growing, and has its origin in the course of the transformation process. A major part of the indebtedness arose from the leasing of the agricultural assets and unsettled liabilities of cooperatives and their legal successors, with respect to eligible persons pursuant to the Act of the Transformation of Co-operatives. Indebtedness has increased the downfall of agriculture. Since 1991 losses have reached 37,1 billion CZK.

Table 1. Economic results of agriculture in the Czech Republic in 1991-1997 (CZK billion)

\begin{tabular}{lllllllll} 
Economic result & 1991 & 1992 & 1993 & 1994 & 1995 & 1996 & 1997 & Total \\
\hline Profit (+), loss (-) & -9.1 & -12.9 & -9.7 & -4.1 & +0.5 & -0.5 & +1.3 & -37.1 \\
\hline Note: & 1) 1994 state farm losses amounting to CZK 3.7 & billion not included \\
Source: & $\begin{array}{l}\text { Results of VÚZ } \\
\text { 1997: } 1]\end{array}$
\end{tabular}


Work productivity is growing quickly, but earnings still lag behind the average for the national economy (the relation is 79.4\%). The main reason for the low earnings of agricultural workers are the 'price scissors' between prices of agricultural products, which grew about 52\% from 1989-1997, and prices of inputs to agriculture, which grew about $231.9 \%$ in the same period.

Agriculture has been undergoing a very radical process of transition during the last ten years. However, the sector is still experiencing serious economic difficulties, arising in particular as a result of:

- inconsistent implementation of the restitution and privatisation process in which a substantial portion of the assets of legal entities was not returned to the original owners, and subsequently operators in primary agriculture were separated from downstream industries;

- low level of farmer integration, especially in the area of the marketing and sale of their products;

- long term disproportion between the growth rates of farm input prices and farmgate prices;

- growth of internal indebtedness when farmers have to save on development and reproductive investments due to unfavourable business conditions;

- significant decline of state intervention in the area of financial support, especially in comparison with our major trade partners;

- low level of market protection, which is especially obvious in comparison with the EU, our dominant partner in agrarian trade;

- restrictions of agricultural production due to public interests which for a number of years have not been compensated;

- application of the Competition Act, which is economically disadvantageous for agriculture as it places the fragmented and less organised farmers on the same level as the financially strong, integrated retail chains. [Report... 1997: 2].

Growing inflation has lowered the living standard of rural inhabitants. Unemployment is significantly higher in agrarian regions than the average for the entire republic $(8.2 \%$ in May 1999). Some trends which have existed in rural areas in the past are continuing with growing intensity.

\section{Through Education to a Civic Society}

At the moment, studies dealing in more detail with the transformation's impact on the life of agricultural workers and rural population are still at the stage of preparations for field research. ${ }^{9}$ Competition on the labour market is known to be keen, and the prestige attached to education is clearly on the rise. This means, however, education not only in agricultural subjects - the decline in the number of people active in Czech agriculture on a regular basis indicates that larger numbers of graduates with a narrow specialisation in solely plant or animal production might not find work in rural areas. Young people's in-

9) See e.g. Majerová, V. et al., Social Trends in Agriculture and the Countryside (grant of the Ministry of Education, Youth and Physical Education for 1997-2000) and Social Change of the Czech Village (grant of the Grant Agency of Czech Academy of Sciences for 1998-2000). 
terests are therefore focused on professions involving knowledge of economics, marketing, management and information technology. Should these young people desire to apply their skills to farming, they will find opportunities in intensive large-scale operations and in medium-sized agricultural undertakings, or in services related to primary agricultural production. Partial findings collected to date suggest that the farming profession's prestige is increasing, particularly when combined with the producer's independence and when the good performance and prospects of the agricultural undertaking in question can be demonstrated.

Agricultural workers as a social group have gone through major ups and downs. Inaccurate and distorted information has formed the public opinion on them - but without them. Their lives unfold outside media policies even today. In addition, agricultural workers lack a mainstay ideology, influential political representation and a functional structure of societies and associations in villages.

The countryside's long-term development is unthinkable without upgrading the level of education. However, not all young people can become successful managers or large-scale producers. The Czech countryside will either become depopulated, or a broad range of various complementary professions and social classes intertwined through civic groups, special-interest associations and political organisations will slowly start emerging within it, and they will keep the countryside viable and liveable. I believe that agriculture can play an important role as a sector providing some degree of security in food supplies and a living for a part of the rural population, solely in certain fertile areas. The fate of the remaining regions will probably be tied to the fate of the Common Agricultural Policy in Europe; this, however, can only be mentioned in the conditional.

VĚRA MAJEROVÁ is a graduate of the College of Agriculture in České Budějovice and the Faculty of Philosophy of Charles University in Prague. During her professional career she has worked in different agricultural companies, and also in the Department of Rural Sociology at the Research Institute of Agricultural Economics in Prague. At this time she is the head of the Department of Humanities of the Czech University of Agriculture Prague. She is engaged in pedagogical and research activities on the subject of rural sociology and agriculture.

\section{References}

Danglová, O. 1995. "Transformácia pol'nohospodárstva jako otáznik pre etnológa [Transformation of Farming as a Question Mark for the Ethnologist]." Slovenský národopis 43, no. 43: 482-492.

Franěk, Rudolf 1967. Některé problémy sociálního postavení rolnictva v Čechách na konci 19. a poćátkem 20. století [Some Problems of the Peasantry's Social Position in Bohemia at the End of the 19th and the Beginning of the 20th Century]. Praha: Academia.

Gillette, J. M. 1928. Sociologie venkova [Rural Sociology]. Praha: Nákladem ústředního svazu agrárních akademiků.

Zelená zpráva [Green Report] 1997. Praha: MZe ČR.

Kaplan, K. 1993. Nekrvavá revoluce [A Non-Bloody Revolution]. Praha: Mladá fronta.

Klement Gottwald 1946-1949, Volume II. 1949. Praha: Svoboda.

Košický vládní program [The Košice Governmental Policy Statement]. 1945. Praha: Ministerstvo informací.

Kubačák, Antonín 1994. Dějiny zemědělství v Českých zemích [History of Agriculture in the Czech Lands], I. díl. Praha: Ministerstvo zemědělství. 
Leščák, M. 1995. “Kolektivizácia pol’nohospodárstva a súčasný etnologický výskum [Collectivisation of Farming and Current Ethnological Research]." Slovenský národopis 43: 378-382.

Majerová, V. 1997. "Sociologice venkova a zemědělství [Rural and Farming Sociology].” Skriptum. Praha: PEF ČZU.

Pekař, Josef 1991. Dějiny československé [Czechoslovak History]. Praha: Akropolis.

Peroutka, Ferdinand 1933. Budování státu [The Building of the State], I. díl. Praha: Fr. Borový.

Petráňová, Lydia 1996. "Zdařené a nezdařené restituce v zemědělství [Successful and Failed Property Restitution in Agriculture].” Pp. 73-84 in Původní a noví vlastníci. Strategie nabývání majetku ve středni a východní Evropě, Cahiers du CEFRES no. 11, June 1996. Praha: Francouzský ústav pro výzkum ve společenských vědách.

Protokol VIII. sjezdu KSČ [Protocol of the 8th Congress of the Communist Party of Czechoslovakia]. 1946. Praha: Kulturní a propagační oddělení sekretariátu ÚV KSČ.

Zpráva o stavu zemědělství ČR za rok 1996 [Report on the Status of Czech Agriculture] 1996. Praha: MZe ČR.

Zpráva o stavu zemédělství ČR za rok 1997 [Report on the Status of Czech Agriculture] 1997. Praha: MZe ČR.

Slavkovský, P. 1995. "Dve diskontinuity vo vývine slovenského pol’nohospodárstva [Two Discontinuities in the Development of Slovak Farming]." Slovenský národopis 43: 371-377.

Stočes, František 1958. Postavení zemědělské malovýroby v kapitalistické ČSR [Position of SmallScale Agricultural Production in Capitalist Czechoslovakia]. Praha: SNPL.

Špirk, Ludvík 1959. Zemědělské družstevnictví v kapitalistické a lidově demokratické ČSR [Farming Co-operatives in Capitalist and People's Democratic Czechoslovakia]. Praha: SNPL.

Tauber, J. 1968. "Vznik sociologie venkova a zemědělství [The Emergence of Rural and Farming Sociology].” Pp. 258-260 in O koncepci dějin československé sociologie. Sborník materiálů ze symposia, Brno, 19-20 června 1967. Brno: Socialistická akademie.

Ústava ČSR [Constitution of the Czechoslovak Republic]. 1948. Praha: Státní nakladatelství. 